\author{
Тәжекеев Ә.Ә. ${ }^{1}$, Тюлебаева Н.Б. ${ }^{2}$ \\ ${ }^{1} \mathrm{PhD}$, Қорқыт Ата атындағы Қызылорда мемлекеттік университетінің \\ «Археология және этнография» ғылыми-зерттеу орталығының жетекшісі, \\ Қазақстан, Қызылорда к., e-mail: azik8484@mail.ru \\ ${ }^{2}$ Қорқыт Ата атындағы Қызылорда мемлекеттік университетінің \\ «Қазақстан тарихы және әлеуметтік-саяси ғылымдар» кафедрасының магистранты, \\ Қазақстан, Қызылорда қ., e-mail: nurgul8486@mail.ru

\section{СЫР ӨНІРІНІН КИЕАІ (қасиетті) ОРЫНААРЫ ЖАЙАЫ КЕЙБІР МӘСЕАЕАЕР}

Мақалада қарастырылатын негізгі мәселе Сыр өңірі киелі орындарының орналасу аймағы тарихы туралы айтылады. Қызылорда облысында мыңдаған тарихи-мәдени ескерткіштердің бар екенін ескерсек, олардың әрқайсысының тарихы, өзіндік ерекшелігі мен құндылықтары бар. Елбасының «Қасиетті Қазақстан» жобасы ұлттық идеология тұрғысынан тың жоба болып табылады. Қасиетті нысандар еліміздің тарихы үшін деректер ғана емес, ол біз үшін мақтаныш тұтып қастерлейтін мұра. Сырдарияның төменгі ағысы бойындағы қасиетті нысандарды танып білуде, олардың қандай көрсеткіштер бойынша киелі болып табылатындығы туралы деректер зерттеу жұмысының басты жаңалығы болып табылады. Зерттеу жұмысы барысында өлкеміздің киелі жерлердің ең белгілісін және болашақта туристік нысандар мен маршруттарға айналатын ескерткіштер таңдап алынды.

Түйін сөздер: Сырдария, киелі, қасиетті, ескерткіш, туризм, археология.

Tazhekeyev A.A. ${ }^{1}$, Tyulebaeva N.B. ${ }^{2}$

${ }^{1} \mathrm{PhD}$, Korkyt Ata Kyzylorda State University, Head of the Center for Archeology and Ethnography, Kazakhstan, Kyzylorda, e-mail: azik8484@mail.ru

${ }^{2}$ Korkyt Ata Kyzylorda State University, Master student of the department «History of Kazakhstan and socio-political sciences», Kazakhstan, Kyzylorda, e-mail: nurgul8486@mail.ru

\title{
Some questions of sacred places in the Syrdarya region
}

The main problem considered in the article is the history of the region of dislocation of sacred places of the earth of Cheese. In the Kyzylorda region are thousands of historical and cultural monuments, each of them has its own history, features and values. The project of the head of state "sacred Kazakhstan» is a new project from the point of view of national ideology. Sacred objects are not only facts for the history of the country, but also a heritage that we are proud of. The main novelty of the research work is the study of the Holy objects along the lower reaches of the Syr Darya, by what indicators they are Holy. During the research, the most famous places of our region were selected, and those monuments that would become future tourist objects and routes were selected.

Key words: Syrdaria, holy, sacred, monument, tourism, archeology.

Тажекеев А.А. ${ }^{1}$, Тюлебаева Н.Б. ${ }^{2}$

${ }^{1} \mathrm{PhD}$, Кызылординский государственный университет имени Коркыт Ата, руководитель Центра археологии и этнографии, Казахстан, г. Кызылорда, e-mail: azik8484@mail.ru

${ }^{2}$ Кызылординский государственный университет имени Коркыт Ата, магистрант кафедры «Истории Казахстана и социально-политических наук», Казахстан, г. Кызылорда, e-mail: nurgul8486@mail.ru

\section{Некоторые вопросы о священных (сакральных) местах в Сырдарьинском регионе}

Основной проблемой, рассматриваемой в статье, является история региона Аислокации сакральных мест земли Сыра. В Кызылординской области расположены тысячи исторических и культурных памятников, каждая из них имеет свою историю, особенности и ценности. Проект главы государства «Священный Казахстан» является новым проектом с точки зрения национальной идеологии. Священные объекты - не только факты Аля истории страны, но и наследие, 
которым мы гордимся. Главной новизной исследовательской работы является изучение святых объектов вАоль нижнего течения Сырдарьи, по каким показателям их относят к святым. В ходе исследования были отобраны наиболее известные места нашего края и те памятники, которые станут будущими туристическими объектами и маршрутами.

Ключевые слова: Сырдария, святой, сакральный, памятник, туризм, археология.

\section{Кіріспе}

Елбасы «Болашаққа бағдар: Рухани жаңғыру» бағдарламалық мақаласында Қазақстанның қасиетті рухани құндылықтарын халық санасына сіңірудің ерекше маңыздылығын айтып өткен болатын. Осыған орай, ҚР Мәдениет және спорт министрлігінің бастамасымен қазақ халқының тарихынан елеулі орын алатын Қазақстанның қасиетті орындарын анықтап, оның тізімін жасау қолға алынды. Ғылыми-сараптамалық кеңесі ашылып, еліміздің облыстық әкімдіктерінің қатысуымен қасиетті орындарды анықтау үшін жұмыс топтары құрылды. Қазақстанның 100 қасиетті орны мен кешендерінің тізімі анықталды. Тізімге Қазақстанның тарихи-мәдени мұрасы мен әлеуметтік саяси өміріндегі маңызды орын алатын нысандар мен кешендер кірді.

Қазақстан бойынша енгізілетін құасиеттінысандар бес топқ̧ажіктелді: Ерекше бағаланатын табиғи мұра ескерткіштері; Археологиялық ескерткіштер және ортағасырлық қалалық орталықтар; Діни және ғұрыптық орындар; Тарихи тұлғаларға қатысты қасиетті орындар; Саяси, тарихи оқиғаларға байланысты қасиетті орындар.

«Қазақстанның киелі жерлерінің географиясы» жобасы аясында Қызылорда облысы бойынша жергілікті өлкетанушылардың ұсыныстары негізінде 12 тарихи ескерткіш еліміздің жалпыұлттық қасиетті нысандар тізіміне және 35 тарихи ескерткіш өңірлік қасиетті нысандар тізіміне енді.

Жалпыұлттық қ̧асиетті нысандар: Ежелгі Шірік-Рабат қалашығы; Ортағасырлық Жанкент қалашығы; Ортағасырлық Сығанақ қалашығы; Ортағасырлық Жент қалашығы; Қорқыт Ата кешені; Бегім ана мұнарасы; Оқшы ата кесенесі; Хорасан кесенесі; Төлегетай-Қылышты кесенесі; Жанқожа батыр мазары; Бұқарбай батыр кесенесі; Христос Спаситель шіркеуі.

Өңірлік қ̧асиетті нысандар: Ежелгі Бәбіш мола қалашығы; Баланды II кесенесі; Жетіасар археологиялық кешені; Ортағасырлық Күйіккескенқала қалашығы; Сауысқандық петроглифтері; Ортағасырлық Асанас қалашығы; Есабыз әулие кесенесі; Асан Ата кесенесі; Асанас Ата кесенесі; Сунақ Ата кесенесі;
Мүлкәлан кесенесі; Мүсірәлі әулие кесенесі; Құлболды ишан кесенесі; Марал ишан кесенесі; Қалқай ишан кесенесі; Айқожа ишан кесенесі; Түмен әулие кесенесі; Қосым қожа бейіті; Қожан қожа кесенесі; Қарасопы кесенесі; Opaзай ишан кесенесі; Ахмет ишан кесенесі; Ала тағы әулие қорымы; Белең ана қорымы; Ақтас мешіті; Ноғай мешіті; Ғанибай мешіті; Қалжанахун мешіт-медресесі; Әбжали ишан мешіті; Иманқұл мешіті; Қожаназар ишан мешіті; Ғанибай үйі; Ашаршылық және саяси қуғынсүргін құрбандарына арналған мемориалдық ескерткіш; Тағзым алаңы; Байқоңыр ғарыш айлағы.

Осы тізімнен бөлек Ә.Х. Марғұлан атындағы Археология институты ғалымдарының тобы, ҚР ҰҒА академигі Б.Ә. Байтанаевтың жетекшілігімен «Қазақстанның киелі орындарының географиясы: Табиғат, археология, этнография және діни сәулет өнері нысандарының тізілімі» (Қазақстанның киелі., 2017) атты еңбекте Сыр өңірінің төмендегі ескерткіштерін қасиетті орын деп танып енгізген.

Айқожа кесенесі; Айтбай мешіті; Ақтас мешіті; Араласар қонысы мен Кердері-2 кесенесі; Асан ата кесенесі; Асанас ата кесенесі; Бегім ана мұнарасы; Бұланды-2 ғибадатханасы; Жанкент қаласы; Жанқожа батыр кесенесі; Жент қаласы; Жетіасар археологиялық кешені; Көтібар батыр мұнарасы; Қалжан ахун мешіт-медресесі; Қалқай ишан кесенесі; Қарасопы кесенесі; Қорасан ата кесенесі; Қорқыт ата мемориалдық кешені; Құтқарушы Христос шіркеуі; Құттыбай кесенесі; Марал ишан кесенесі; Мүлкалан кесенесі; Оқшы ата кесенесі; Сараман қоса (Сарман қожа) мұнарасы; Сауысқандық петроглифтері; Сығанақ қаласы; Түгіскен қорымы; Шірікрабат қалашығы.

Осы жасалған екі тізім ішінде қасиетті орындар категориясының талаптарына жатпайтын нысандар да бар. Тізімге енбей қалған қанша ескерткіштерді де атап өту керек. Бұл жаңа басталған жоба болғандықтан асығыс немесе деректердің аз болуына байланысты деп есептейміз. Мысалы, Ғанибай үйі, Ашаршылық және саяси қуғын-сүргін құрбандарына арналған мемориалдық ескерткіш, Тағзым алаңы 
ескерткіштері тарихи-мәдени мұралар тізімінде болғанымен, олармен байланысты аңыздар мен хикаяттардың болмауы, киелі орын ретінде ел арасында мойындалмағандығын ескеру қажет. Сонымен қатар, ортағасырлық Кескен Күйікқала, Асар-асар қонысы, Кердері-2 кесенесі ескерткіштері де ортағасырлық қоныс түрлері мен жерлеу құрылысының қиранды ізі ғана. Олар жайлы жазба немесе аңыз әңгімелер сақталмаған. Елбасы атап кеткендей, кез келген ескерткішті киелі орынға айналдырып, жобаның сапасына сын келмес үшін, санға емес сапаға, нысанның тарихи құндылығына қарап, оны киелі немесе қасиетті орын деп танып, зерттеп, насихаттап қана қоймай, қорғау, сақтау шараларын да қатар жүргізіп отырған маңызды.

Қазақстанның киелі нысандарының бастауы тарих қойнауына тереңдеп кететін мыңдаған жылдық тарихы бар. Олар әр түрлі және мазмұны мен өзіндік типологиялық сипаттамасы бойынша ерекшеленеді. Еліміздің әрбір аймағындағы киелі нысандардың қазіргі таңдағы жағдайы бірдей емес. Олар орналасу орнына, урбанизация деңгейіне, қызмет етуі мен оның қорғалуының ұйымдастырылуына байланысты. Киелі нысандардың типологиялық құрамы да біртекті емес. Бірінші кезекте бұған тарихимәдени мұра нысандары: діни сәулет өнері құрылыстары, қалалар, қоныстар, қорымдар, зираттар, молалар, ғибадатханалар, жартас суреттері, тарихи оқиғалар орны, тарихи ландшафты және т.б. жатады. Ерекше топқа халық киелі деп таныған табиғат нысандары: тау, шоқы, бұлақ, өзен, шатқал, ағаш, үңгір, жекелеген табиғи ландшафттар және т.б. нысандар кіреді (Қазақстанның киелі., 2017, 904).

Сыр өңірінің киелі орындарының мерзімделуі, тарихы және аныздары. Сыр өңірін археологиялық тұрғыдан зерттеудің бірнеше бағытта өрбігендігін аса маңызды ашылулармен атап өтуге болады. Арал маңының неолит және энеолит дәуірлеріне, географиялық кең түсінікпен қарағанда, ортаазиялық «қосөзен» Сырдария мен Әмудария аймағында ежелден өркениеттер ізі сақталған. Өлкемізде біздің заманымыздан бұрынғы VI-III мыңжылдықтардың өзінде туыстас тайпалардың қоныстануы аңғарылады. Олардың экономикасы қарапайым, яғни, аңшылық және балық аулау кәсіптері еді.

Бұл мәдениеттің үлкен тұрақтары (Сексеуіл, Көнту, Ақеспе, Қара-сандық, Шөлқұм, Тәмпі т.б.) Солтүстік Арал маңы мен Кіші Борсық құмдарынан табылды. Олар өмір сүруге жай- лы, суға жақын аймақтарда орналасқан. Тастан жасалған еңбек құралдарынан басқа, қой, сиыр және құланның сүйектерінің табылуы алғашқы қауымдық тайпалардың отарлап мал өсіру кәсібіне өткендігін көрсетеді.

Міне, көне заманнан өркениет ізі өшпеген Сырдың бойында қасиетті тұтатын жерлер көптеп кездеседі және олардың тарихы тереңнен басталады. Сол себепті тарих көзімен қарағанда кешегі, яғни, кейінгі ортағасырлық пантеонға айналған ірі қорымдар немесе киелі саналып кеткен тарихи орындарға тоқталмас бұрын өңіріміздің киелі (қасиетті) орындарының орналасуы, мерзімделуі және ерекшеліктерін талдауды жөн санадық. Олар: Қола дәуірінің қасиетті орындары (б.з.д. IX-VIII ғғ.); Сақтардың киелі орындары (б.з.д. VIII-VII ғғ.); Құмға көмілген қалалар. Шірікрабат мәдениеті (б.з.д. IV-II ғғ.); Жетіасар жәзирасында жайқалған қалалар (б.з. I мыңжылдығы); Ортағасырлық ордалы қалалар (IX-XVI ғғ.); Кесенелер қасиеті (XI-XIX ғғ.); Табиғи қасиетті нысандар.

1. Қола дәуірінің қ̧асиетті орындары: Солтүстік Түгіскен кесенелері (Итина, 2001).

2. Сақтардың киелі орындары: Ұйғарақ және Оңтүстік Түгіскен қорымдары (Вишневская, 1973).

3. Құмzа көмілген қалалар. Шірікрабат мәдениеті: Шірік-рабат қала-қорымы; Бәбішмола қалашығы; Баланды кешені (Құрманқұлов, Жетібаев, 2011; Құрманқұлов, 2011; Толстов, 1962 Yerdan O., Tazhekeyev A., 2016, p.137-144.).

4. Жетіасар жәзирасында жайқалган қалалар: Жетіасар мәдениетінің 50-ге жуық қалалары (Левина, 1996).

Ел аузындағы көне аңыздар осы Жетіасар қалалары жайлы сақталған. Олардың бірі Жетіасар қалаларын әлемге әйгілі Ақсақ Темірдің атымен байланыстырса, енді бірі Алтын асар атанған қаланы алтын қорыған айдаһары бар мекен деп сенген. Келесі бір аңызда қатар қонған қалалардың билеушілері арасындағы жаугершілік сипатталады (Қоңыратбаев, 1994, 148$153)$.

5. Ортавасырлық ордаль құалалар: Оғызқыпшақ кезеңінде орын алған үздіксіз соғыстар мен қақтығыстарға, саяси-этникалық жағдайлардың шиеленісуі мен өлкедегі табиғиэкологиялық ахуалдың өзгеріске ұшырауына қарамастан Сырдарияның төменгі ағысын мекендеген тұрғындар IX-XII ғғ. осы аймақта ортағасырлық қала мәдениетін жасап, дамыта алды. Сырдарияның ескі арналарының 
бассейндеріндегі оғыз-қыпшақтардың бекініс жүйесі мықты қалалары олардың көршілес Хорезм және Шығыс Еуропа елдерімен арадағы саяси, экономикалық, мәдени байланыстарында маңызды роль атқарды.

Сырдың бойында жүздеген ортағасырлық қалалар бар. Бірақ, олардың ішінен оғыздардың астанасы болған Жанкент, Жент, қыпшақ хандығының, Ақ Орда мемлекетінің және Қазақ хандығының астанасы - Сығанақ қалашықтары ортағасырлық киелі мекендер санатына жатады. Оларға атақты Асанас, Баршынкент, Сауран сияқты ірі шаһарларды қосуға болады.

Осы аталған қалалар жайлы көптеген аңыздар, жазба деректер, ipi зерттеулер бар. Соларды ішіндегі Жанкент шаһары аңыздар ел арасында кеңінен сақталған (Қоңыратбаев, 1994, 148-153; Ежелгі қала - Жанкент, 2010).

6. Кесенелер қ̧асиеті: Бұл кезеңге жататын Қызылорда облысы аймағында бірнеше жүздеген қазақ мазарлары мен қорымдары бар. Соларға қысқаша талдап, алдыңғы зерттеулерге тоқталсақ.

Мемориалды-ғұрыптық құрылыстардың (туыстық қорымдар (молалар) және ірі туыстық жерлеу қорымдары) Арал маңындағы малшыкөшпенділердің индикаторы ретінде тарихи маңызы зор. XIV-XVII ғғ. қазақ халқының ғұрыптық сәулет өнері: тастан жасалған, қам кесектен және күйдірілген кірпіштен тұрғызылған кесенелер, «төртқұлақ» түріндегі қоршаулар, саркофаг-жәшіктер, бағана тастар (құлпытастар) және т.б. мемориалды-ғұрыптық кешеннің қалыптасуына негіз болды.

Ғұрыптық құрылыстардан Ақтас, Балдық және Қалжан ахун мешіттері қызығушылық тудырады. Ақтас мешіті Сырдарияның төменгі ағысы бойындағы монументалды-күмбезді құрылыс болып табылады. Мешіттің ғимараты күйдірілген кірпіштерден тұрғызылып, негізгі жоспарында шаршы пішінді болып келеді. Қазіргі кезде ғимараттың ішкі көрінісіне өзгерістер енгізілген.

Сырдарияның төменгі ағысындағы белгілі Қалжан ахун мешіті өзі қайтыс болғаннан кейін жанұялық қабірге айналған. Ескерткіш - зор көркемдік және тарихи маңызға ие.

Дала күзетшісі секілді алыстан мұнарланып тұратын мұнаралар Сырдың төменгі ағысы аймақтарында ғана кездеседі. Олардың саны 50-ге жуық. Мұнараларға ғылыми зерттеулер жүргізген архитектор Э.М. Байтенов оларды тек Сыр өңіріне ғана тән екендігін айтады. Бегім ана, Сараман-Қоса және Ұзынтам мұнараларын бүгінде халық киелі санап кеткен.

X-XI ғғ. мерзімделетін Бегім ана мұнарасы Қызылорда облысы, Әйтеке би кентінен батысқа қарай 68 шақырым қашықтықта орналасқан.

Ескерткіш төңірегінен биіктеу жайдақ төбеде орналасқан. Офицер А.И. Макшеев айтып өткендей мұнара «төбе үстінде тұр, шамасы, ол жер кезінде арал болған сияқты, Қараарықтан төрт қарым, Арал теңізінің жағалауынан 10 қарым.. бұл жерде Қызылбаш Шаншар ханның әйелі жерленген». Мұнара қатты бүлінген қам кесектерден тұрғызылған қоршау түріндегі жерлеу құрылыстары бар қорымда орналасқан. Мұнара жөнінде ешқандай анық мағлұмат жоқ, халық арасында кең тараған аңызға сүйенсек, ескерткішті Жанкент қаласының билеушісі Санжардың әйелімен байланыстырады. Сол аңыздың желісі бойынша, күйеуінің тарапынан жазықсыз реніш тапқан жас тоқалы құсқа айналып, осы құрылысқа мәңгі тұрақтап қалған (Макшеев, 1896, 68-69; Байтенов, 2007, 281-282; Тәжекеев, 2017, 498-500).

Сырдың ежелгі арналары Іңкәрдария мен Жаңадария бойында қарахандар дәуіріне жататын ерекше сәулет өнерінің туындылары орналасқан. Іңқардариялық Сырлы там мен жаңадариялық Сырлы там кесенелері Сыр бойындағы күйрілген кірпіштен салынған ғұрыптық құрылыстардың сақталған алғашқы үлгілері болып табылады.

Ортағасырлық кесенелер қатарында Оқшы ата, Асан ата, Жүніс ата, Қасым ата кесенелерінен сәулет өнерінің ерекше белгілерін байқауға болады. Алғашқы екі ескерткіш Сырдарияның төменгі ағысындағы (XI-XII ғғ.) тұңғыш мұсылмандық кесенелердің қатарында және құндылығы жағынан зор маңызға ие. Қызылордадан Сығанаққа барар жолда орналасқан бұл ірі қорым оғыз-қыпшақ дәуірінің пантионы десек те болады.

XVI-XX ғасырдың басындағы кесенелер тобы күйдірілген кірпіштен тұрғызылып, Сырдарияның төменгі ағысы бойына ислам дінін әкелген араб дін таратушыларының ұрпақтарымен байланысты-Мүлкәлән (Молда-калан), Қорасан ата, Қылышты ата, Асанас ата, Қожан Қожа, Сүнбибі (Шынқыз әулие), Құлболды ишан, Айқожа ишан, Қарасопы кесенелерін атауға болады.

Қазақ мемлекеттілігінің қалыптасуындағы алғашқы ғасырлармен байланысты ескерткіштер - атап айтсақ, найман тайпаларының негізін 
қалаушылардың бірі Төлегетай ата кесенесі. Қам кесектен тұрғызылған ғұрыптық қоршаулар Алатағы қорымы мен Белең ана, сондай-ақ атақты мерген Байғана кесенесі, Бөрібай батыр және Бесқыз қорымындағы (Бестам) кесенелер де ерекше сәулет өнерінің туындылары. Олар Сарысу өзенінің төменгі ағысы мен Телікөл (Телекөл) көлінің маңайында орналасқан.

XIX-XX ғасырдың бас кезеңіне жататын кесенелер зиратхана (тілеухана) - ғұрыптық ic-әрекеттерге, Құран және намаз окуға арналған бөлмесі бар кесенелер тобы Сарысу өзенінің төменгі ағысы мен Телікөл (Телекөл) көлінің маңайында ғана кездеседі. Бұндай кесененің композициясынан осы өңірге тән қазақ кесенелеріндегі екі камералы құрылысты архитектуралық нұсқаның қалыптасқанын көреміз. Оның жоғары деңгейдегі көркем үлгілері Құлтан, Мұқылтам (қазіргі кезде сапалы жөндеу жұмыстары жүргізілді), Ахмет ишан, Ақтай кесенелері.

Сарысу өзенінің төменгі ағысындағы мемориалды қоршаулар: соның ішінде Шағатай қорымындағы қоршаулар. Осы құрылыстарға тән ерекшелік-ескерткіштердің жоғары деңгейдегі тепе-теңдігі (тіпті біреуі қисық сызық сұлбалы болып келген құрылыспен жабылған). XX ғасырдың бас кезеңіне жататын күйдірілген кірпіштен соғылған қоршаулар осы аймақта анықталып, зерттелді. Олар Бәтеш тамы, Едігенің мемориалды қоршауы, Сарымола (Қызылмола) екі қоршауы.

Қызылорда қаласынан батысқа қарай, қам кесектерден тұрғызылған қазақтың күмбезді ескерткіштері қызығушылық тудырады: олар әртүрлі композициялық тақырыптағы Көтібар батыр кесенесі, Қосүйтам деп аталатын (Нияз және Мәмбетбақи), Пұсырманбай (ішінде араб графикасында жазылған бедерлі жазуы бар құлпытас орналасқан), Байсалбай, Жеңістам (Жиенес), Жылкелді, Толыбай батыр кесенелері.

Күйдірілген кірпіштен тұрғызылған Сарлыбай, Келімбет және Құттыбай кесенелерінің ерекшелігі - күмбезінің нақышты, әдемі болуында. Күмбездің сапалы қаландылары ішкі жағында айқын көрінеді, тегіс қатарлы қаландылар күмбез асты құрылыстармен үйлесе қиюласқан. Олардың арасында көркемдік мол безендіруге ие Құттыбай кесенесі.

Мавзолейлер сыртқы фасады өте бай безендірілген және өзіндік сипаты бар күмбездерімен ерекшеленеді. Мысалы, Құттыбай мавзолейіндегі кірпіштен қолданылған безендірілу элементтері, бүгінгі таңда осы өңірдегі ұста-шеберлердің ағаштан жасалған түрлі композицияларында орын алған (Байтенов, 2007, 272-273).

Бастауын ежелден алған, XVIIIғ. аяғы - XIXғ. жататын, өзіндік архитектуралық ерекшелігі бар қазақ мавзолейлері, мешіттері және мұнаралары Орта Азия және Қазақстан архитектурасында ғылыми қызығушылық туғызып отырған қазақ халқының ерекше архитектуралық туындылары Сырдың қасиетті жерлерінің географиясын байыта түсері сөссіз.

7. Табиви қ̧асиетті нысандар: Табиғат нысандарына келер болсақ, ғалымдардың пікірінше олардың біршама ертелері, әдеттегідей, ғасырлар қойнауына тереңдеп кететін киелі дәстүрі бар болғанымен, мұндағы істің жағдайы күрделірек. Соңғы уақыттарда ғана «қасиетті» деп танылған нысандар да бар (қасиетті немесе емдік бұлақтар, үңгірлер және т.с.с), ал бұларды кие тұту бақылаусыз түрде өрістеген деп те айтуға болады. Олардың көпшілігінің мәртебесі ресми түрде анықталып болған жоқ. Нысандардың басым көпшілігі тәуелсіздік алғаннан кейінгі уақыттарда коммерциялық мақсатта пайда болып, нәтижесінде Қазақстандағы зиярат ету туризмін дамытты. Олар терең зерттелмеген және жан-жақты зерттеулер мен ғылыми сараптамадан өткізуді қажет етеді.

\section{Қорытынды}

Қалыптасқан тарихи тұрғыдан Қазақстан аумағын шартты түрде бірнеше тарихимәдени аймаққа бөлуге болады. Олар мазмұндық жағынан археологиялық және тарихи ескерткіштер көрініс табатын өз ішінде біршама тығыз байланыстарымен, дамуының ортақтығымен, табиғи-экологиялық және әлеуметтік-мәдени факторлардың сәйкес келуімен ерекшеленеді. Елдің орталығын алып жатқан Сарыарқа тарихи-мәдени кеңістігі (ареал) қазақ тарихы мен мәдениетінде ерекше орын алатын Қазақстандағы ең үлкен аймақтың бірі. Ол Ұлытаудан Тарбағатай тауына дейін созылып жатыр. Оған батысынан - Арал-Каспий кеңістігі, оңтүстіктен - Сырдария-Қаратау мен Жетісу, шығысынан - Алтай жалғасады (Қазақстанның киелі., 2017, 904).

Осы жерде аты айтып тұрғандай Сырдария өзені, Қаратау жоталары, Арал теңізі, Барса- 
келмес аралық халқымыздың бойына ғасырлар бойы сіңген қасиетті табиғи нысандар қатарына жатқызуға болады. Бұл тізімге ертеден сыр мен қырды жайлай қоныстанған Арал маңы, Қарақұмы мен Қызылқұм құмды массивтерін, Сарысу өлкесін де қосуға болады. Халқымыз мекен еткен, көшіп-қонған аймағына атауын беріп ата қоныс ретінде қасиетті мекенге айналдырып отырған. Өлкемізде қанша елді мекен болса, сонша тарих, табиғи нысандар бар. Бірақ, иісі қазаққа танымал табиғи атауларды жоғарыда келтіріп өттік.

Мақ̧ала ҚР БҒМ ҒК құаржыландыратын №AP05131086 «Сырдарияның төменгі авысындагы құалальқ мәдениеттің құалыптасу барысында түркі-овыздардың Арал маңъының отырықщы-егінші тайпаларымен этномддени байланысы (б.з. І мыңжжылдывы)» жобасы бойыншиа дайындалган.

\section{Әдебиеттер}

Байтенов Э.М. (2007). Мавзолей Куттыбай . Свод памятников истории и культуры РК. Кызылординская область. Алматы.

Байтенов Э.М. (2007). Мавзолей Мунара Бегим-ана . Свод памятников истории и культуры РК. Кызылординская область. Алматы. С. 281-282.

Вишневская О.А. (1973). Культура сакских племен низовьев Сыр-Дарьи в VII-V вв. до н.э. Труды ХАЭЭ, VIII, Москва.

Ежелгі қала - Жанкент. (2010). Қызылорда.

Итина М.А., Яблонский Л.Т. (2001). Мавзолеи Северного Тагискена. Поздний бронзовый век Нижней Сырдарьи. Москва.

Қазақстанның киелі орындарының географиясы: Табиғат, археология, этнография және діни сәулет өнері нысандарының тізілімі. Алматы: Ә.Х. Марғұлан атындағы Археология институты, 2017, 1-шығарылым. 904 б.

Қоңыратбаев Т. (1994). Ертедегі ескерткіштер. Алматы. 148-153-бб.

Құрманқұлов Ж. (2011). Шірік-рабат ескерткішіндегі - 2004-2010 жж. археологиялық зерттеулер . Мыңжылдық куәлары: Қазақстан археология ғылымы 20 жылда (1991-2011) Алматы.

Құрманқұлов Ж., Жетібаев Ж. (2011). Шірік-рабат қалашығы . Қазақстан Республикасының тарихи және мәдени ескерткіштерінің жинағы. Қызылорда облысы. Алматы.

Левина Л.М. (1996). Этнокультурная история Восточного Приаралья (в I тыс. до н. э. - I тыс. н. э.). Москва.

Макшеев А.И. (1896). Описание низовьев Сырдарьи. Санкт-Петербург, 1896. С. 68-69.

Тәжекеев Ә.Ә. (2017). Бегім ана мұнарасы . Қазақстанның киелі орындарының географиясы: Табиғат, археология, этнография және діни сәулет өнері нысандарының тізілімі. Алматы: Ә.Х. Марғұлан атындағы Археология институты, 2017, 1-шығарылым. 498-500 бб.

Толстов С.П. (1962) По древним дельтам Окса и Яксарта. Москва.

Yerdan O., Tazhekeyev A., Meirmanova G., Darmenov R., Bilalov S., Amirgalina G. (2016) Monuments of the Early Iron Age of the Aral-Caspian Region as a Historical Source. Journal Abbreviation: Anthropologist, 26 (1, 2): 137-144 (2016) Kamla-Raj 2016. JOURNAL IMPACT FACTOR DETAILS. Journal ISSN: 0972-0073.Scopus. p.137-144.

\section{References}

Baytenov E.M. (2007). Mavzoley Kuttybay [Kuttybai Mausoleum] . Svod pamyatnikov istorii i kultury RK. Kyzylordinskaya oblast [The set of historical and cultural monuments of the Republic of Kazakhstan. Kyzylorda Region]. Almaty, 2007.

Baytenov E.M. (2007). Mavzoley Munara Begim-ana [Mausoleum of Munara Begim-ana] . Svod pamyatnikov istorii i kultury RK. Kyzylordinskaya oblast [The set of historical and cultural monuments of the Republic of Kazakhstan. Kyzylorda Region]. A1maty, 2007. S. 281-282.

Vishnevskaya O.A. (1973). Kultura sakskikh plemen nizovyev Syr-Dari v VII-V vv. do n.e. [The culture of the Saka tribes of the lower Syr Darya in the VII-V centuries. BC.] Trudy KHAEE, VIII [Proceedings of the KhAEE, VIII]. M., 1973.

Yezhelgi kala - Zhankent (2010). [The ancient city of Zhankent]. Kyzylorda,

Itina M.A., Yablonskiy L.T. (2001). Mavzolei Severnogo Tagiskena. Pozdniy bronzovyy vek Nizhney Syrdari [Mausoleums of Northern Tagisken. Late Bronze Age of the Lower Syr Darya]. Moskva, 2001.

Kazakhstannyn kiyeli oryndarynyn geografiya: Tabigat, arkheologiya, etnografiya, zhane díni saulet oneri nysandarynyn tizilimi [Sacred geography of Kazakhstan: Register of objects of nature, archeology, ethnography and cult architecture]. Almaty: A.KH. Margulan atyndagy Arkheologiya instituty, 2017, 1-shygarylym. 904 b.

Konyratbayev T. (1994). Yertedegi yeskertkishter [ancient monuments]. Almaty, 1994. 148-153-bb.

Kurmankulov ZH. (2011). SHirik-rabat eskertkishindegi - 2004-2010 zhzh. arkheologiyalyk zertteuler [In Chirik-Rabat Monument - 2004-2010 archeological researches] . Mynzhyldyk kualary: Kazakhstan arkheologiya gylymy 20 zhylda (1991-2011) [Millennium Testimony: Archeology of Kazakhstan in 20 years (1991-2011)]. Almaty, 2011. 
Kurmankulov ZH., Zhetibayev ZH. (2011). SHirik-rabat kalashygy [Chirik-Rabat Monument] . Kazakhstan Respublikasynyn tarify zhane madeni yeskertkishterinin zhinagy. Kyzylorda oblysy [The set of historical and cultural monuments of the Republic of Kazakhstan. Kyzylorda Region]. Almaty, 2011.

Levina L.M. (1996). Etnokulturnaya istoriya Vostochnogo Priaralya (v I tys. do n.e. - I tys. n.e.) [History of the Eastern Aral Sea region (in the 1st millennium BC - the 1st millennium BC).]. Moskva, 1996.

Maksheyev A.I. (1896). Opisaniye nizovyev Syrdari [Description of the lower reaches of the Syr Darya.]. Sankt-Petersburg, 1896. S. 68-69.

Tazhekeyev A.A. (2017). Begim ana munarasy [Begim Ana Tower] . Kazakhstannyn kiyeli oryndarynyn geografiya: Tabigat, arkheologiya, etnografiya zhane dini saulet oneri nysandarynyn tizilimi Sacred geography of Kazakhstan: Register of objects of nature, archeology, ethnography and cult architecture]. Almaty: A.KH. Margulan atyndagy Arkheologiya instituty, 2017, 1-shygarylym. 498-500 bb.

Tolstov S.P. (1962). Po drevnim deltam Oksa i Yaksarta [According to the ancient deltas of Oks and Yaksart]. Moskva, 1962.

Yerdan O., Tazhekeyev A., Meirmanova G., Darmenov R., Bilalov S., Amirgalina G. (2016). Monuments of the Early Iron Age of the Aral-Caspian Region as a Historical Source. Journal Abbreviation: Anthropologist, 26 (1, 2): 137-144 (2016) Kamla-Raj 2016. JOURNAL IMPACT FACTOR DETAILS. Journal ISSN: 0972-0073.Scopus. p.137-144. 